\title{
Local Online Courier and Ride-Hailing Service Social Media Marketing
}

\author{
Ilyas Lampe ${ }^{1, a)}$ Raisa Alatas ${ }^{2)}$ Nifi Orynka ${ }^{3)}$ Gemilang Bayu Ragil Saputra ${ }^{4)}$ \\ ${ }^{1}$ Department of Communication Studies, Universitas Tadulako, Indonesia \\ a) author correspondence: ilyaslampe7@gmail.com \\ ${ }^{2,3,4}$ Department of Communication Studies, Universitas Tadulako, Indonesia
}

DOI: https://doi.org/10.18196/jkm.131051

Article Info

Article history:

Received 07 Oct 2020

Revised 29 Dec 2020

Accepted 14 Apr 2021

\section{ABSTRACT}

Topokeni was a local online courier and ride-hailing service in Palu. In this study, we tried to understand the social media marketing strategies used by Topokeni, as we assumed that Topokeni had specific strategies to compete with national and international scale ride-hailing services such as Grab and Gojek. Thus, this study was focused and aimed to understand and describe the Instagram marketing strategies of Topokeni based on four aspects of social media marketing in a qualitative-case study approach. Data were collected through in-depth interviews, observations, and document study on social media and other relevant archives. The results showed that social media became an alternative to survive and increase tenants and consumers. In the context aspect, Topokeni admins used nicknames such as kakak (bro/sis) to their customers to reach broader targets. In the communication aspect, Topokeni used graphic elements in photos, videos, infographics, and testimonials posts. In the collaboration aspect, Topokeni merged the tenant's market with Topokeni's customers. In the connectivity aspect, Topokeni synergized the contents, themes, and brand positioning using \#kurirpalu and \#deliverypalu, also@(mention) feature on partner tenant accounts and personal customers as a form of appreciation and responsibility.

Keywords: Marketing; online courier; ride-hailing service; social media; topokeni

\section{ABSTRAK}

Topokeni merupakan layanan ojek dan kurir online lokal di Palu. Dalam penelitian ini kami mencoba melihat bagaimana strategi pemasaran Topokeni melalui media sosial dengan asumsi awal bahwa Topokeni memiliki strategi pemasaran tertentu yang menjadikan Topokeni dapat bersaing layanan ojek dan kurir online berskala nasional dan internasional seperti Grab dan Gojek. Sehingga, penelitian ini berfokus pada dan bertujuan untuk menjabarkan dan memahami strategi pemasaran melalui Instagram yang dilakukan oleh Topokeni berdasarkan model penelitian kualitatif menggunakan pendekatan studi kasus melalui empat aspek pemasaran media sosial. Data dikumpulkan melalui wawancara mendalam, observasi langsung dan studi dokumen pada media sosial dan arsip-arsip yang relevan. Hasil dari penelitian ini menunjukkan bahwa media sosial menjadi alternatif untuk bertahan dan meningkatkan rekanan dan pelanggan. Berdasarkan context, admin Topokeni menggunakan panggilan kakak untuk merujuk pelanggan dengan dasar untuk mencapai target pasar yang lebih luas. Dalam aspek communication, Topokeni menggunakan elemen desain grafis pada postingan foto, video, infografis dan testimonial. Untuk collaboration, Topokeni meleburkan pasar rekanan dengan pelanggan Topokeni sendiri. Dalam aspek connectivity, Topokeni mensinergikan isi, tema dan brand positioning dengan menggunakan \#kurirpalu dan \#deliverypalu, serta penggunaan fitur @ (mention) pada akun media sosial rekanan dan pelanggan sebagai bentuk tanggung jawab dan apresiasi.

Keywords: Media sosial; kurir online; ojek online; pemasaran; topokeni 


\section{INTRODUCTION}

High human mobility is not only caused by the demands of rapid work but also the availability of increasingly diverse modes of transportation (Freudendal-Pedersen, 2020). Society nowadays, especially in urban areas, need rapidity and punctuality. An inevitability arises with the advances of communication technology that can be integrated with innovations (Cornet et al., 2019; Wu, Liu, \& Yuan, 2020), thus changing the landscape of our civilization, especially mass transportation services (Zhang \& Lu, 2020).

The integration of transportation with information and communication technology triggered smartphone-based transportation applications, giving rise to new transportation service giants such as Grab and Go-Jek (Silalahi, Handayani, \& Munajat, 2017). This transportation service has eventually displaced conventional modes of transportation such as taxis (Alemi, Circella, Mokhtarian, \& Handy, 2019). Thus, the community's behavior also shifted to other types of developed services such as food and groceries (Bissell, 2020).

The shift of development does involve not only service utilization aspects and consumption patterns (Bissell, 2020) but also opens opportunities for local business activities (Silalahi et al., 2017). Internet-based transportation services and applications are growing very fast, ranging from large-scale companies that encompass all regions of Indonesia (Silalahi et al., 2017) to small-scale that only exist in one city or local-scale. As the Capital of Central Sulawesi Province, Palu has several online couriers and motorcycle taxi services, including the local online courier and motorcycle taxi services, Topokeni, as the object of this study.

Social media is used to disseminate information (Idris, 2019) and as a means of promotion (Jaafar, Darmawan, \& Ariffin, 2018). The rapid growth of the use of social media to promote transportation services cannot be separated from the reality that the people are so infatuated with using smartphone applications in their daily lives (Jaafar et al., 2018; Ministry of Communication and Informatics, 2013), especially with Instagram (Pertiwi, 2019). Not only as a social network to share photos, but Instagram is also often used to market business products. Instagram reached more than one billion users (Bohang, 2018), and sixty-one million of them are active users in Indonesia (Pertiwi, 2019).

Gojek and Grab are two multinational companies that are pioneers in providing motorcycle taxi and online courier services, or ride-hailing, in Indonesia. Gojek and Grab run their business with a profit-sharing system of $20 \%$ for the company and $80 \%$ for drivers. Grab and Gojek have three basic principles in their business models: speed, innovation, and social impact. In addition to extensive revenue sharing, drivers who join also get health and accident benefits and access more customers through the application (Silalahi et al., 2017). Grab, as the most significant transportation application in Southeast Asia, is developing in Indonesia in stages. Like Grab, Gojek was founded in Jakarta in 2010 by Nadiem Makarim, an alumnus of the Harvard School of Business. Gojek service is available in the Jakarta area, Bali, Bandung, Surabaya, Makassar, Medan, Palembang, Semarang, Yogyakarta, Balikpapan and Palu in late 2017.

The massive growth of online courier and taxi services has made the competition even stronger (Alemi et al., 2019). All kinds of strategies driven by financial factors become the primary aspects of winning the competition (Maryani, Rahmawan, \& Karlinah, 2020). Local-scale online courier and motorcycle taxi service that is not supported by adequate capital is an exception. The presence of multinational ride-hailing operators such as Grab and Gojek in Palu increases the market and competition. Topokeni, as a representation of local online courier and ride-hailing services, requires precise and fast classification in the face of competition. One example of the strategy is to take advantage of the knowledge regarding the market characteristics of Palu and introduce Topokeni as a local product with closer ties to the community.

Topokeni was established in 2013 by Adhiguna Kharismawan, which is motivated by the condition of Palu. According to its founder, this courier service is an effective solution to facilitate the mobility and needs of Palu people, who are often constrained to travel due to hot weather. Compared to Grab or Gojek, Topokeni is very different in technology applications, capital, and business scale. Technology-wise, Topokeni does not yet develop an application. The marketing was done using Instagram and Whatsapp. By utilizing Instagram and Whatsapp, Topokeni actively marketizes and promotes its services and cooperation with partnerships and creates a more contemporary image.

Also, compared to Grab or Gojek, whose cumulative fees totaled by distance or fixed fees for few first Kilometers and additional fees added per Kilometers, Topokeni took a different approach to how the fees were calculated. Topokeni divided the fees into two different groups area A (rayon A, 
consisted of downtown Palu centered on Topokeni's headquarter) and area B (rayon B, consisted of border areas of Palu such as Karanja Lembah, Palupi, Gawalise, and Tawaeli). Outside of those two areas, Topokeni can provide services, but it is more of contract or agreement-based hauling, especially cross-regency hauling. As such, Topokeni, as stated from the initial interview, can maintain 30 delivery or hauling orders daily, which is entirely sustainable and constant for a local scale ridehailing service.

The development of communication and information media has changed the marketing landscape of goods and service products. The rapid development of technology also affects the media of communication. The shift to the digital era means an increase in digitalization. New media will change the meaning of geographical distance, increase the volume of communication, give the possibility of increasing the speed of communication, provide opportunities for interactive communication, allow previously separate forms of communication to overlap and be interconnected (Croteau \& Hoynes, 2003). Thus, by the power of computerization, media of communication evolved further into what is known as new media. One available new media product is social media, which is made possible by the internet as an extension. Social media offers various advantages, making the business world look at social media as a potential marketing medium based on the concentration of people (user) gathered (Aditya \& Irawan, 2013). The proximity of social media to many people who are becoming the brand's target consumers makes social media also a favorite media for marketers.

The development of the internet followed by the presence of social media opened great potential and opportunity and become a new medium in marketing communication (Nicolas Alarcón, Urrutia Sepúlveda, Valenzuela-Fernández, \& Gil-Lafuente, 2018). Social media is defined as a group of internet-based applications that use Web 2.0 ideology and technology to create or exchange information on the application (Kaplan, 2015). Widely used social media in Indonesia are Facebook, Twitter, Instagram, Youtube, and Blogspot (Doni, 2017; Pertiwi, 2019).

Social media allows users to increase their media literacy by communicating with other users who are scattered randomly throughout the world (Filipan-Zignic, Legac, Pahic, \& Sobo, 2015). Social Media allows marketers to form a public voice and presence on the web and strengthen other communication activities (Grizane \& Jurgelane, 2016; Yadav, Joshi, \& Rahman, 2015). As many as 1 in 5 internet users in Indonesia have interacted with brands or companies through social media (Nielsen, 2014). As such, media of communication reach a new level of media literacy needs in which crucial for social media users, as one of the most popular products of the internet (Chen, $\mathrm{Lin}, \mathrm{Li}, \&$ Lee, 2018). The presence and ease of access to social media open a new way of communication for average users and business owners not only for public relations purposes but also to market their products and services (Rosyadi, 2018). Therefore, the role of social media in helping brand marketing both new and well-known brands in Indonesia is considered impactful (Nielsen, 2014).

Practitioners divide social media into six main platforms (Aditya \& Irawan, 2013; Evans, 2008; Putri, 2018). First, social news sites allow users to send news, information, articles, videos, and photos, which will then be given a rating (vote, like, or dislike) of that information, such as digg.com or reddit.com. Second, social networking allows building networks among users with more diverse choices such as Facebook and Linkedin. Third, social sharing allows users to share contents with others to create exciting and liked content features, such as Instagram, Youtube, and Flickr. Fourth, the blog focuses on ones' efforts to express themselves in articles of ideas, thoughts, and information. Fifth, microblogging focuses on writing messages or information with limited spaces. Sixth, the forum became a place for varied discussions from hobbies, trends, and even politics.

Internet marketing model that became known as Social Media Marketing was a marketing goal by participating in various social media networks (Constantinides, 2014; Stoica, Pitic, \& Bucur, 2014). Social media marketing tools generally include BBS, microblogging, blogs, SNS, images and videos. There are four aspects of social media marketing: 1 . Context, which is how we frame our stories; 2. Communication, which is the practice of sharing our stories and listening, responding, and growing; 3. Collaboration, which is working together to make things better and more efficient and effective; and 4. Connection, which is the relationships we forge and maintain (Arief \& Millianyani, 2015; Solis, 2010).

Social media as a marketing medium can also be seen as a persuasive interaction and communication effort with potential consumers, which refers to the context of integrated marketing communication (Kotler \& Keller, 2016). Persuasive interaction and communication efforts are made to build sustainable interactions with customers and prospective customers (Alhammad \& Gulliver, 
2013). Thus, this study was mainly focused on social media usage as a marketing platform, specifically on how Topokeni used Instagram as a marketing medium.

Integrated marketing communication is the development of the marketing mix. The marketing mix itself is a set of controlled marketing variables that companies use to produce company-controlled responses from the target market (Kotler \& Keller, 2016). The marketing mix consists of everything the company can do to influence demand using product, price, place, and promotion (Kotler \& Keller, 2016). These four strategic variables significantly affect marketing, so they are all important as a unified reference or mix strategy, especially for social media-based marketing (Elena, 2016). In service marketing, the strategic approach is directed at the marketer's ability to find ways to understand the intangible, increase the productivity of providers, create quality standards in connection with variability, and influence the movement of demand and supplier capacity (Priansa, 2017). The marketing also focuses on using all forms of promotion to achieve the maximum impact or communication effect.

However, different views were expressed by Schultz, who assesses the definition as narrow or limited, and does not describe the actual integrated marketing communication (Schultz \& Schultz, 2004). Schultz wants a broader perspective that takes into account all available resources (Schultz \& Schultz, 2004). Schultz believes that consumers' perception of the company, industry, or its trademark is a synthesis of the various messages consumers receive or contacts they have. The message or contacts may include product advertising in the mass media, product prices, product designs or forms, publications, sales promotions, direct marketing, websites, product displays, and even stores or outlets where the products are sold. Thus, the company or industry must develop a total marketing communication strategy.

The current study, nevertheless, departed from past research on marketing strategy and competitive intelligence of Grab and Gojek (Dewi \& Darma, 2019). The study by Dewi and Darma showed the adaptability of Grab where omni-channel marketing (combining offline and online channels in a marketing 4.0 pattern) was heavily utilized to promote and market their services in which enable Grab to compete regionally (Dewi \& Darma, 2019). Similar research on social media usage for marketing of multinational ride-hailing services such as Gojek and Grab was done by Gunawan, whose research focused on social media campaign and online promotion and their effect on to purchase intention of Gojek in Surabaya (Gunawan, 2020). The research shows that social media campaigns and online promotion did significantly affect purchase intention (Gunawan, 2020). Further research which focused on customer loyalty of Grab was done by Surya which stated that marketing mix was affecting customer satisfaction which in turn was affecting customer loyalty (Surya, 2019). The aforementioned studies discussed social media usage for marketing efforts as part of a way to increase the brand awareness of Gojek (Wahid \& Puspita, 2017) and gain an overall competitive advantage for Grab (Widyatama et al., 2020).

The novelty of this study lies in the focus and subject of this study itself which is a local scale ride-hailing service. In contrast, all past and similar research were focused on more multinational and global or international scale ride-hailing services. We assumed that a smaller, local scale ride-hailing service had a different struggle to communicate their service with target audiences than more wellknown services. As such, derived from past and similar research, this study was based on the initial assumption that Topokeni, a local scale ride-hailing service, had specific marketing strategies to compete with national and international scale ride-hailing services such as Grab and Gojek in Palu area. This initial assumption is also retraced because Topokeni had not yet developed a stand-alone app and still use instant messaging service (Whatsapp and Instagram's direct message or DM) to interact with customers. As such, the purpose of this study is to understand and describe the Instagram marketing strategies used by Topokeni. The aforementioned strategies are discerned based on four aspects of Social Media Marketing: context, communication, collaboration, and connection. Using these four aspects, we can break down the marketing strategies by analyzing Instagram posts of Topokeni and its tenants.

\section{METHOD}

This study utilized a qualitative method with a case study approach. Data were collected using indepth interviews with relevant informants and direct observation on how the service operates and Topokeni's Instagram (@Topokeni_Palu) as a marketing medium. Document study of similar research regarding social media marketing was also used to enrich the data analysis. The informants 
were purposively selected based on the established criteria of (1) understood the social media strategies, models, and tools used by Topokeni; (2) used Instagram for personal use and or business use; and (3) a part of Topokeni's marketing network (Topokeni admins and tenants). The informant identities are hidden as per the informant's request, and related data will be labeled using informant initials. Collected data were analyzed using qualitative data analysis in which data were categorized into four categories based on four aspects of Social Media Marketing (context, communication, collaboration and connection). Data were validated by cross referencing from different sources (direct observation with interviews and vice versa), followed by data presentation and conclusion drawing.

\section{RESULT AND DISCUSSION}

\section{Context and Communication of Topokeni's Instagram Posts}

In this first part of the research results, we decided to combine context and communication aspects. This decision is based on the collected data, which showed that the two aspects mentioned above go hand in hand in Topokeni's Instagram posts.

Context means forming a story or message (information), language use, and the contents of the message (Arief \& Millianyani, 2015; Solis, 2010). This understanding shows the power of language in conveying messages which becomes the main thing to form an impression. The use of local language for Topkeni is important to show who Topokeni is and who their customers are. From the very beginning, Topokeni has chosen to be emotionally close to his customers, who inevitably influence the used language.

Based on the context, an agreement was made and became the Standard Operational Procedure (SOP) between the Topokeni admins/operators, couriers, and customers. The use of kakak (literally translated as bro or sis) as a greeting is universal and assumed to be able to close the age gap between the courier, operator and the customer for mutual respect to grow without being too formal. This use of kakak is evident from several Instagram posts of Topokeni where admins greeted Topokeni customers with the words hai kakak-kakak (literally translated as "Hi, brothers and sisters"). Likewise, when responding to chats on Whatsapp, said greeting is also used.

The use of such words represents respectful yet relaxed interaction and relationship with their customers. In addition to the greeting, other aspects such as weather conditions could be used as a base for building persuasive communication. For example, Topokeni's caption on one of their Instagram post (fig. 1): Kakak-kakak hujan gini enaknya ngopi, tapi kendalanya ke luar rumah becek, jasa Topokeni siap mengantarkan kopi kakak-kakak, atau kakak-kakak mau makan, ingin beli sesuatu ayuks kakak langsung hubungi Topokeni. Kami siap memberikan pelayanan yang terbaik (Bro/Sis, this rain calls for coffee, but if you guys do not want to get wet in this pouring rain, we are ready to deliver your hot coffee. Likewise, contact us if you are hungry and your food will be delivered. We are ready to provide the best service for our Bro/Sis)

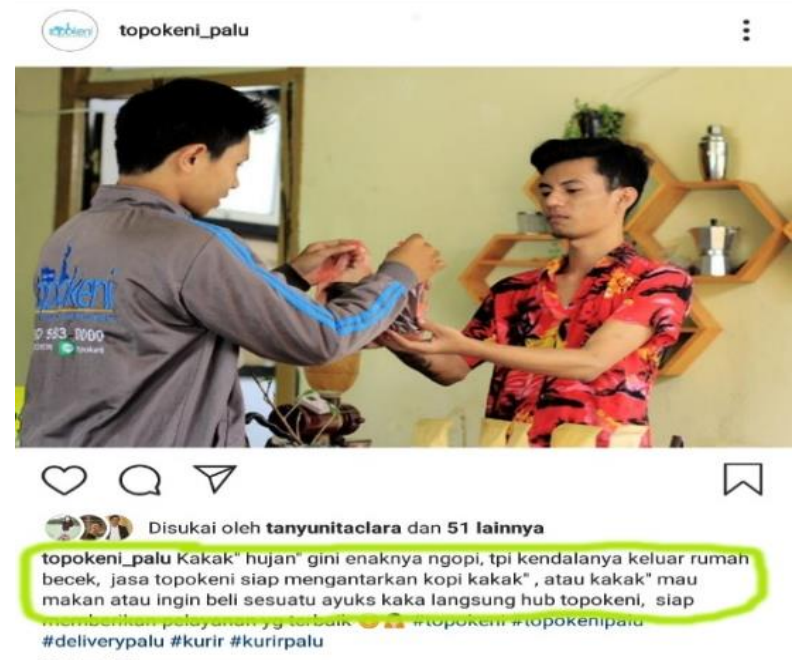

Figure 1. Persuasive communication built based on the weather context 
Furthermore, an important element that is emphasized in compiling messages (information) that makes users feel comfortable and the messages conveyed well is by emphasizing attractive visuals and graphics. With a good and neat design, the customers feel attracted and positively respond to what is offered by Topokeni.
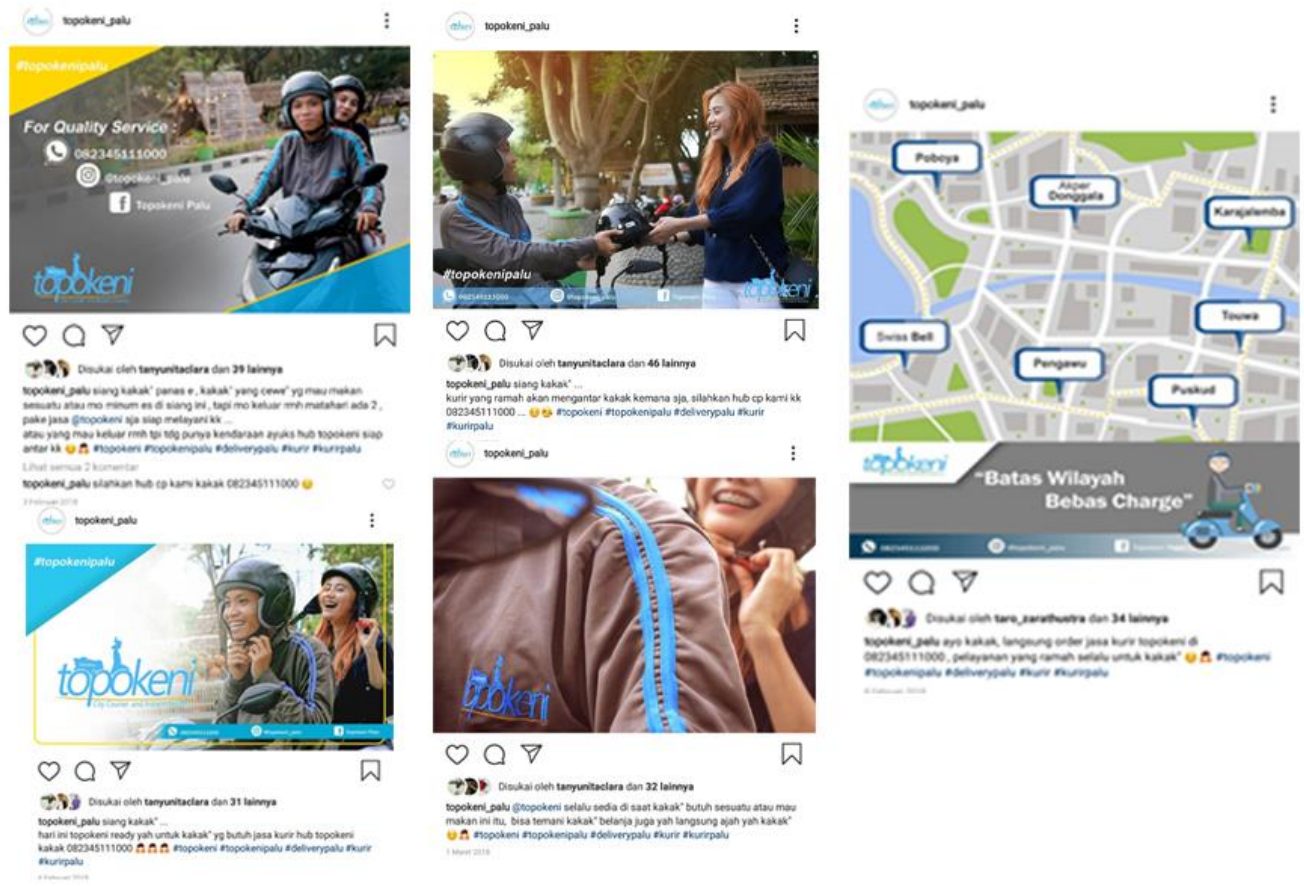

Figure 2. Designs and infographics based Promotional Posts

Topokeni also featured several posts regarding the testimonials of their customers in using provided services. This testimony is crucial as a form of accountability, transparency, and appreciation to customers, showing the professional side of Topokeni's services. Finally, the combination of designs, photos, videos, and testimonials on Topokeni posts constructs an image of a professional online courier and ride-hailing service provider.

\section{Collaboration with Tenants}

Collaboration in this aspect refers to how working together makes things better, more efficient, and practical (Solis, 2010). In this study, collaboration refers to the cooperation between concerned parties to formulate efficient and effective social media marketing methods. In this section, we describe how Topokeni collaborates both with its tenants or followers or Instagram users of Palu.

The collaboration effort of Topokeni's social media marketing is shown by introducing accounts or companies that used Topokeni's services. Promotional activities become more effective and efficient by collaborating with Instagram accounts of restaurants, companies, or shops. For example, the collaboration with Ayam Geprek Bensu is often promoted through Topokeni's Instagram account. Through the highlights and story features of Instagram, the collaboration is visible.

The collaboration with tenants' Instagram accounts is implemented in the form of recommendations along with Topokeni's delivery service. Thus, a harmonious and continuous relationship between Topokeni and tenants is essential to be maintained. While the use of Instagram influencers or selebgrams and Topokeni buzzer accounts has not been done, a different step is to collaborate with media and figures of Palu with active followers.

"We do not use buzzers or selebgrams. Because in our opinion, selebgrams and buzzers cannot be ascertained whether or not the followers are active and the scope is within Palu. We are better off cooperating with some people with more than 1000 followers and at least $80-90 \%$ active netizens of Palu. We think it is more effective." (Informant AK, 18 May 2019)

The decision to avoid using buzzers is explicitly to avoid uncontrolled opinions in the comment section and detrimental association with the negative image that usually came with the utilization of buzzers (Neyasyah, 2020). It is stated that Topokeni does not collaborate with any selebgrams, 
specifically that of a full-blown national scale selebgrams. Instead, Topokeni opted to collaborate with Instagram users of Palu that have more than 1000 followers. This decision is made to build a more approachable image and trigger a word-of-mouth (WOM) type of situation between followers.

Compared to Grab or Gojek, Topokeni is considered small. Thus, limiting and focusing its scope by directly collaborating with tenants is a more manageable strategy for Topokeni. By directly collaborating with tenants, Topokeni merged both Topokeni's and their tenant's target audience or customers, hence simplifying the communication efforts to market and promote their services.

\section{Connectivity with Followers and Customers}

On the connectivity aspect, maintaining relations that have been fostered is crucial. Sustainable interaction and collaboration make users feel much closer and involved (Solis, 2010). For Topokeni, connectivity stands to maintain and continue connecting tenants and individual customers through promotional and marketing opportunities. Topokeni's management represented the connectivity aspect on their Instagram account using \# (hashtag) and @ (mention) features.
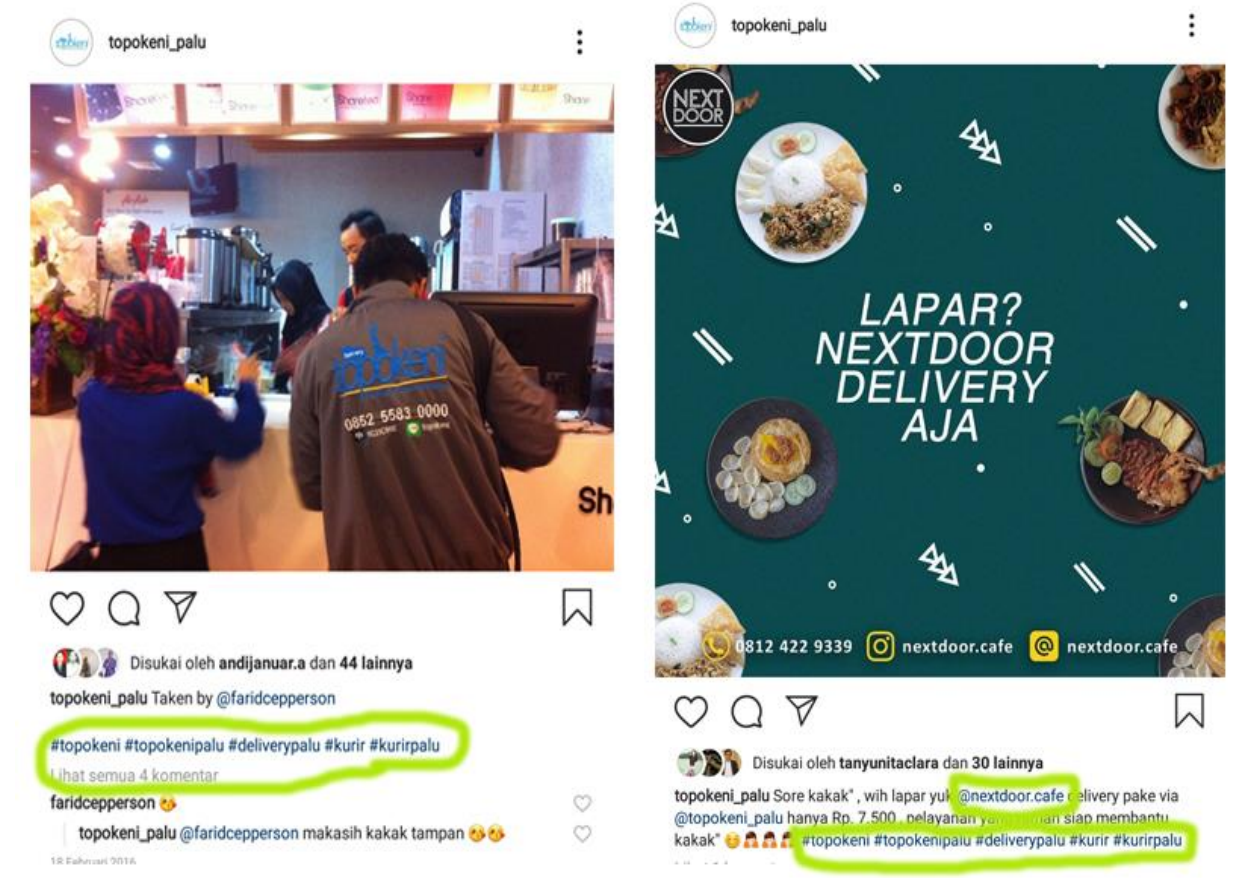

Figure 3. The use of \# (hashtag) and @ (mention) on Topokeni's posts

The use of \# by Topokeni can be seen as a group of post themes and to facilitate netizens in searching specific themes. For example, by including \#kurirpalu on their posts, coverage can be attained through search and other related posts. In addition to theme grouping and making it easier to search, \# is also used as brand positioning. In every post that Topokeni has on their Instagram feed, brand positioning with \#deliverypalu placed Topokeni as an online courier and ride-hailing service in Palu. From two months of observation, there are about 729 posts that use \#deliverypalu. Of these 729 posts, two online courier and ride-hailing services are identified, and one of which is Topokeni.

As for the use of @ (mention), Topokeni often synergizes with tenants or figures that became the focus of the post. For example, Topokeni will use @ to identify the partner or customer Instagram tenant accounts on their posts. The use of @ is done to facilitate netizens, especially followers of Topokeni, to be easily directed to tenants or figures' accounts.

"Mentioning (through @) the concerned person or tenant for us is beneficial. Aside from being a form of interconnected ties, it is also a form of appreciation. It is more fun to use mention than tags, as mention can be directly coupled with a caption to make a whole caption. For example, one of the most mentioned is Geprek Bensu.” (Informant I, 18 May 2019)

Other than using mention features, Topokeni also regards the traffic variable of orders for each tenant. Simply put, high traffic of orders on one tenant is to be maintained using mentions. However, 
if other tenants' traffic is low, the use of mention feature is increased in a non-obstructive way in the posts' caption.

Topokeni itself did not have any working applications such as Grab or Gojek. Thus, Topokeni utilizes both Whatsapp and Instagram's direct messaging (DM). Aside from the financial and scale aspect of Topokeni, the decision to utilize both Whatsapp and Instagram DM rather than to build a fully working application is to build a firm foundation within the community, considering Indonesia was the fourth largest Whatsapp users in 2019 with 59.9 million users (Tankovska, 2021).

Another defining factor that supports the decision to utilize Whatsapp and Instagram DM based on the interviews is that both Whatsapp and Instagram DM also build a sense of familiarity and conversation between Topokeni, tenants, or customers compared to the more self-service model of Grab and Gojek. While Grab's and Gojek's fully working application approach is more stable and efficient in the long run (Alemi et al., 2019; Widyatama et al., 2020), it is limited and more suited to when the service is well known to the public.

Integrated Marketing Communication is one part of marketing management which consists of advertising, public relations and sponsorship, personal selling, direct marketing, and sales promotion, which are integrated and support each other (Belch \& Belch, 2015; Jucaitytė \& Maščinskienė, 2014). The existence of Integrated Marketing Communication makes a company or industry can target market share effectively and appropriately (Grizane \& Jurgelane, 2016; Jucaityte \& Maščinskiené, 2014). Integrated Marketing Communication is not only focused on the marketing side of things but also on the communication side. This includes but is not limited to communication efforts to instill brand awareness or build a brand image that relies on persuasive communication forms. In this case, Integrated Marketing Communication is used to bridge the use of media of communication (social media Instagram) as a marketing media by Topokeni.

Topokeni could spread service and ideas to available and prospective customers by understanding social media marketing strategy through context, communication, collaboration, and connectivity. The existence of Topokeni as an online courier and ride-hailing service provider can be said to be well developed. The available market gap and competition between larger ride-hailing services is an opportunity that must be maintained by management (Alemi et al., 2019; Silalahi et al., 2017). However, the use of social media in marketing is not always the right choice to increase sales or consumer loyalty, because in many cases, social media is more effective in terms of brand campaigns and brand identity building (Christou, 2015; Poecze, Ebster, \& Strauss, 2018; Putri, 2018; Rahman \& Noor, 2014; Rashid, Cohen, \& Ghose, 2018). Table 1 shows the collected and analyzed data on Topokeni's social media marketing.

Table 1. Topokeni's social media marketing strategy

\begin{tabular}{|c|c|c|c|}
\hline No. & $\begin{array}{c}\text { Social Media Marketing } \\
\text { of Topokeni }\end{array}$ & Implementing Instructions & $\begin{array}{l}\text { Implementation in } \\
\text { Instagram accounts }\end{array}$ \\
\hline 1 . & Context & $\begin{array}{ll}\text { 1. } & \begin{array}{l}\text { Market } \\
\text { segmentation by }\end{array} \\
\text { age. } \\
\text { 2. }\end{array}$ & 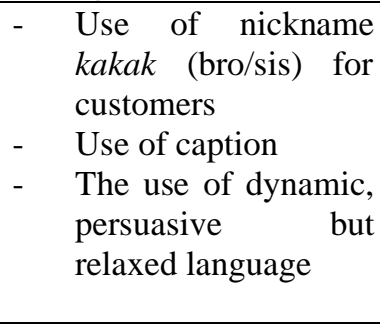 \\
\hline 2. & Communication & $\begin{array}{l}\text { The use of graphic design } \\
\text { elements such as: } \\
\text { 1. Placement, } \\
\text { 2. Colour, } \\
\text { 3. Lines, } \\
\text { 4. Typography }\end{array}$ & 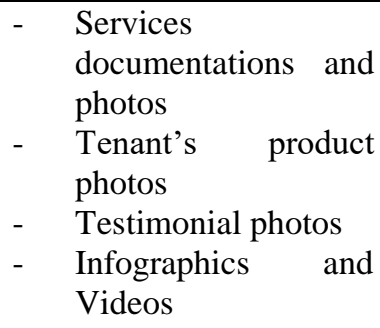 \\
\hline
\end{tabular}

\begin{tabular}{l} 
3. Collaboration $\begin{array}{c}\text { Mixing and merging the } \\
\text { tenant's }\end{array}$ markets with product photos and customer \\
\hline
\end{tabular}




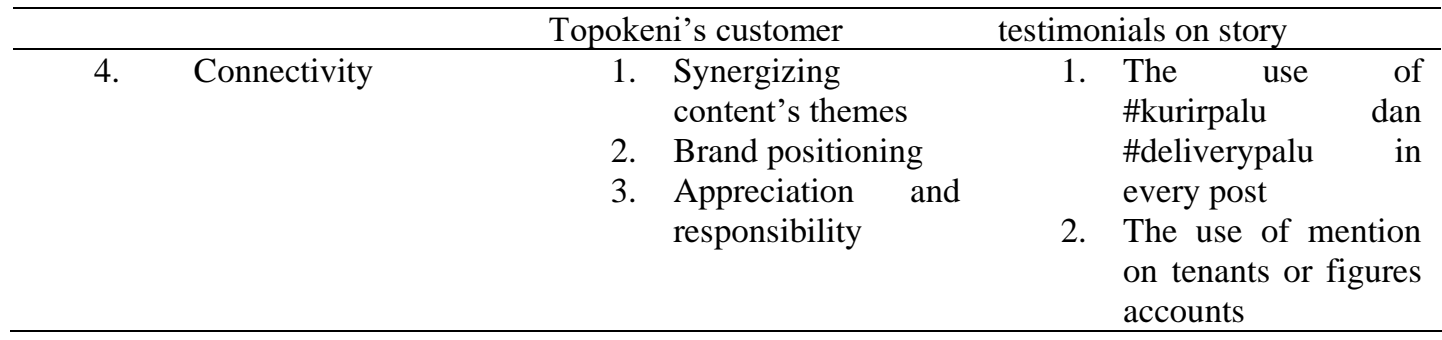

Table 1 could discern Topokeni's base ideas related to social media marketing and their implementation on the Instagram account (@Topokeni_Palu). However, several things have not been implemented by Topokeni, which allows for a good impact on expanding the market share of Topokeni. The first is the use of the promotion post feature provided by Instagram for marketing accounts. The second is the lack of addtools usage as an interactive feature. The third, furthermore, Topokeni has not used analytics tools to evaluate their Instagram account's performance.

One of many edges that Topokeni has over other competitors in online delivery and ride-hailing services is the local product image, thus increasing the relatability within local communities in Palu. In such an instance, it can be said that Topokeni uses local product image as a brand. By adopting the local product brand, Topokeni can differentiate itself from other competitors (Hidayat, Hafiar, \& Anisti, 2019). Another strategy can be adapted from this local product brand image of Topokeni. Topokeni can build campaigns or posts which target each specific ethnicity within the local community of Palu to increase its brand exposure and relatability (Rasyid, 2019). Targeting specific ethnicity within the local community of Palu does not mean changing the entire brand image of Topokeni. Topokeni admins can elevate a relatable point within a post with target ethnicity, which can be done by cooperating with Topokeni's tenants, for example using Kaili language, presenting a trivial fact of Kaledo when promoting Kaledo restaurants and local hangout spots. Some form of this strategy was implemented, but looking from Topokeni’s Instagram posts, but was sparsely used.

\section{CONCLUSION}

Social media became an alternative for local online ride-hailing business activities in Palu. Social media is used to survive and try to get a niche market that has not been explored by multinational online motorcycle taxies such as Grab and Go-Jek. Social media marketing is conducted by Topokeni, which can be broken down into four aspects: context, communication, collaboration, and connectivity. In the context aspect, Topokeni uses kakak as a nickname for customers which further build a dynamic, persuasive yet relaxed interaction. In the communication aspect, graphic design elements are used as outlined in service photos, videos, designs, and testimonials. In the collaboration aspect, Topokeni mix and merge their tenant's market and Topokeni's customers using tenant's product photos highlight posts and testimonials in Instagram stories. Last, in the connectivity aspect, Topokeni synergizes the theme of content and brand positioning by using \#kurirpalu and \#deliverypalu on their posts. A form of appreciation and responsibility is also shown by using the @ (mention) feature on partner and customer accounts.

From the four aspects mentioned above, we discern that Topokeni has certain strategies that enabled Topokeni to compete with Gojek and Grab, at least in Palu and its surrounding areas. Topokeni's strategies are based on the central focus of information dissemination to the population of Palu. This focus can be seen from the fact that Topokeni and its tenants often go hand in hand in promoting their service. By collaborating with local accounts (Instagram users in Palu) with a significant number of followers, Topokeni can assure that most active followers are the users who reside in Palu. The interaction with customers is also crucial to Topokeni's strategies. By using instant messaging services (Whatsapp and Instagram's direct message or DM), Topokeni can directly interact with customers and an approachable image was built.

Future research focusing on the impact of Topokeni's Social Media Marketing Strategy is advisable. Comparative research between a local ride-hailing service (such as Topokeni) and more well-known national or international scale ride-hailing services such as Gojek, Grab, and Uber is also recommended to establish references for new business in online courier and ride-hailing services. 


\section{REFERENCES}

Aditya, A., \& Irawan, Y. R. (2013). Social Media Nation, 15 Inspirasi Berjejaring Sosial. Jakarta: Prasetiya Mulya Publishing.

Alemi, F., Circella, G., Mokhtarian, P., \& Handy, S. (2019). What drives the use of ridehailing in California? Ordered probit models of the usage frequency of Uber and Lyft. Transportation Research Part C: Emerging Technologies, 102(May 2018), 233-248. https://doi.org/10.1016/j.trc.2018.12.016

Alhammad, M. M., \& Gulliver, S. R. (2013). Context relevant persuasive interaction and design: Consideration of human factors influencing B2C persuasive interaction. Proceedings of the International Conference on Information Technology Interfaces, ITI, 161-166. https://doi.org/10.2498/iti.2013.0493

Arief, G. M., \& Millianyani, H. (2015). Pengaruh Social Media Marketing Melalui Instagram Terhadap Minat Beli Konsumen Sugar Tribe. Universitas Telkom.

Belch, G. E., \& Belch, M. E. (2015). Advertising and Promotion: An Integrated Marketing Communication Perspective, Fourth Edition (4th ed.). New York: Mc-Graw Hill.

Bissell, D. (2020). Affective platform urbanism: Changing habits of digital on-demand consumption. Geoforum, (December 2019). https://doi.org/10.1016/j.geoforum.2020.06.026

Bohang, F. K. (2018). Juni 2018, Pengguna Aktif Instagram Tembus 1 Miliar. Retrieved April 27, 2020, from kompas.com website: https://tekno.kompas.com/read/2018/06/21/10280037/juni2018-pengguna-aktif-instagram-tembus-1-miliar

Chen, D. T., Lin, T. Bin, Li, J. Y., \& Lee, L. (2018). Establishing the norm of new media literacy of Singaporean students: Implications to policy and pedagogy. Computers and Education, 124, 1-13. https://doi.org/10.1016/j.compedu.2018.04.010

Christou, E. (2015). Branding Social Media in the Travel Industry. Procedia - Social and Behavioral Sciences, 175(1955), 607-614. https://doi.org/10.1016/j.sbspro.2015.01.1244

Constantinides, E. (2014). Foundations of Social Media Marketing. Procedia - Social and Behavioral Sciences, 148, 40-57. https://doi.org/10.1016/j.sbspro.2014.07.016

Cornet, H., Stadler, S., Kong, P., Marinkovic, G., Frenkler, F., \& Sathikh, P. M. (2019). User-centred design of autonomous mobility for public transportation in Singapore. Transportation Research Procedia, 41, 191-203. https://doi.org/10.1016/j.trpro.2019.09.038

Croteau, D., \& Hoynes, W. (2003). Media Society: Industries. Images, and Audience. Third Edition. Thousand Oaks, CA: Pine Forge Press.

Dewi, M. V. K., \& Darma, G. S. (2019). The Role of Marketing \&amp; Competitive Intelligence In Industrial Revolution 4.0. Jurnal Manajemen Bisnis, 16(1), 1. https://doi.org/10.38043/jmb.v16i1.2014

Doni, F. R. (2017). Perilaku Penggunaan Media Sosial Pada Kalangan Remaja. IJSE - Indonesian Journal on Software Engineering, 3(2), 15-23.

Elena, C. A. (2016). Social Media - A Strategy in Developing Customer Relationship Management. Procedia Economics and Finance, 39(November 2015), 785-790. https://doi.org/10.1016/S2212-5671(16)30266-0

Evans, D. (2008). Social Media Marketing: An Hour a Day. Indianapolis: Wiley Publishing.

Filipan-Zignic, B., Legac, V., Pahic, T., \& Sobo, K. (2015). New Literacy of Young People Caused by the use of New Media. Procedia - Social and Behavioral Sciences, 192, 172-179. https://doi.org/10.1016/j.sbspro.2015.06.025

Freudendal-Pedersen, M. (2020). Sustainable urban futures from transportation and planning to networked urban mobilities. Transportation Research Part D: Transport and Environment, 82, 102310. https://doi.org/10.1016/j.trd.2020.102310

Grizane, T., \& Jurgelane, I. (2016). Social Media Impact on Business Evaluation. Procedia Computer Science, 104(December 2016), 190-196. https://doi.org/10.1016/j.procs.2017.01.103

Gunawan, D. (2020). Pengaruh social media campaign dan online promotion terhadap purchase intention pada Gojek Indonesia di Surabaya. Jurnal Strategi Pemasaran, 7(1).

Hidayat, D., Hafiar, H., \& Anisti. (2019). Tofu Product Branding for Culinary Tourism of Sumedang, Indonesia. Komunikator, 11(2), 82-92. https://doi.org/10.18196/jkm.112022

Idris, I. K. (2019). Government Social Media in Indonesia: Just Another Information Dissemination Tool. Jurnal Komunikasi: Malaysian Journal of Communication, 34(4), 337-356. https://doi.org/10.17576/jkmjc-2018-3404-20 
Jaafar, N. I., Darmawan, B., \& Ariffin, M. Y. M. (2018). Social networking site adoption in Malaysia and Indonesia. Jurnal Komunikasi: Malaysian Journal of Communication, 34(1), 115-134. https://doi.org/10.17576/JKMJC-2018-3401-07

Jucaitytė, I., \& Maščinskienė, J. (2014). Peculiarities of Social Media Integration into Marketing Communication. Procedia - Social and Behavioral Sciences, 156(April), 490-495. https://doi.org/10.1016/j.sbspro.2014.11.227

Kaplan, A. M. (2015). Social Media, the Digital Revolution, and the Business of Media. International Journal on Media Management, 17(4), 197-199. https://doi.org/10.1080/14241277.2015.1120014

Kotler, P., \& Keller, K. L. (2016). Marketing Managment. New York: Pearson.

Maryani, E., Rahmawan, D., \& Karlinah, S. (2020). The implications of social media on local media business: Case studies in Palembang, Manado and Bandung. Jurnal Komunikasi: Malaysian Journal of Communication, 36(1), 317-333. https://doi.org/10.17576/JKMJC-2020-3601-18

Ministry of Communication and Informatics. (2013). Kominfo: Pengguna Internet di Indonesia 63 Juta Orang. Retrieved April 27, 2020, from kominfo.go.id website: https://kominfo.go.id/content/detail/3415/kominfo-pengguna-internet-di-indonesia-63-jutaorang/0/berita_satker

Neyasyah, M. S. (2020). Legal Resilience in the Phenomenon of Social Media Political Buzzer in Indonesia. Proceedings of the 3rd International Conference on Law and Governance (ICLAVE 2019). Paris, France: Atlantis Press. https://doi.org/10.2991/aebmr.k.200321.044

Nicolas Alarcón, C., Urrutia Sepúlveda, A., Valenzuela-Fernández, L., \& Gil-Lafuente, J. (2018). Systematic mapping on social media and its relation to business. European Research on Management and Business Economics, 24(2), 104-113. https://doi.org/10.1016/j.iedeen.2018.01.002

Nielsen. (2014). Media Penetration Q1. USA.

Pertiwi, W. K. (2019). Sebanyak Inikah Jumlah Pengguna Instagram di Indonesia? Retrieved April 27, 2020, from kompas.com website: https://tekno.kompas.com/read/2019/12/23/14020057/sebanyak-inikah-jumlah-penggunainstagram-di-indonesia\#: :text=Jumlah tersebut naik tipis dari,yang mencapai 49\%2C2 persen.

Poecze, F., Ebster, C., \& Strauss, C. (2018). Social media metrics and sentiment analysis to evaluate the effectiveness of social media posts Social media metrics and sentiment analysis to evaluate the effectiveness of social media posts. Procedia Computer Science Portugal Flora Poecze et Al. Procedia Computer Science, 130(130), 660-666. https://doi.org/10.1016/j.procs.2018.04.117

Priansa, D. J. (2017). Perencanaan dan Pengembangan SDM. Bandung: Alfabeta.

Putri, V. K. A. (2018). Media Sosial Terintegrasi dalam Komunikasi Pemasaran Brand: Studi Komparasi Pemanfaatan Media Sosial Oleh High dan Low Involvement Decision Brand. Jurnal Komunikasi Indonesia, 4(2), 108-115. https://doi.org/10.7454/jki.v4i2.8889

Rahman, N. A. A., \& Noor, S. M. (2014). The role of brand self-relevance in developing brand loyalty: A study on the brand loyalty for honda. Jurnal Komunikasi: Malaysian Journal of Communication, 30(2), 91-116. https://doi.org/10.17576/jkmjc-2014-3002-06

Rashid, S. M., Cohen, D., \& Ghose, K. (2018). An exploration on the process of brand identity building in the context of Malaysian cafe. Jurnal Komunikasi: Malaysian Journal of Communication, 34(2), 105-120. https://doi.org/10.17576/JKMJC-2018-3402-07

Rasyid, H. A. N. (2019). The Effect of Ad Model Ethnicity on Advertising. Komunikator, 11(1), 3850. https://doi.org/10.18196/jkm.111018

Rosyadi, M. I. (2018). Analisis Strategi Marketing Public Relations PT. Bank Rakyat Indonesia (Persero) tbk dalam Meningkatkan Pengguna Kartu Brizzi. Komunikator, 10(1), 1-9. https://doi.org/10.18196/jkm.101001

Schultz, D. E., \& Schultz, H. F. (2004). IMC - The next generation: Five steps for delivering value and measuring returns using marketing communication. New York: Mc-Graw Hill.

Silalahi, S. L. B., Handayani, P. W., \& Munajat, Q. (2017). Service Quality Analysis for Online Transportation Services: Case Study of GO-JEK. Procedia Computer Science, 124, 487-495. https://doi.org/10.1016/j.procs.2017.12.181

Solis, B. (2010). Engage: The Complete Guide for Brands and Businesses to Build Cultivate and Measure Success on The Web. New Jersey: John Wiley \& Sons. 
Stoica, E. A., Pitic, A. G., \& Bucur, C. (2014). New Media E-marketing Campaign. Case Study for a Romanian Press Trust. Procedia Economics and Finance, 16(May), 635-640. https://doi.org/10.1016/S2212-5671(14)00851-X

Surya, A. P. (2019). CUSTOMER LOYALTY FROM PERSPECTIVE OF MARKETING MIX STRATEGY AND CUSTOMER SATISFACTION: A Study from Grab - Online Transportation in Era of Industrial Revolution 4.0. MIX: Jurnal Ilmiah Manajemen, 9(3), 394-406.

Tankovska, H. (2021). Leading countries based on number of WhatsApp users in 2019. Retrieved 4 June, 2021, from statista.com website: https://www.statista.com/statistics/289778/countrieswith-the-most-facebook-users/

Wahid, U., \& Puspita, A. E. (2017). Upaya Peningkatkan Brand Awareness PT. Go-Jek Indonesia Melalui Aktivitas Marketing Public Relations. Jurnal Komunikasi, 9(1), 31. https://doi.org/10.24912/jk.v9i1.265

Widyatama, G. W., Chelliah, S., Kai, Y., Yingxing, Y., Tien, Y. C., Mey, W. C., \& Sin, L. G. (2020). Grab Marketing Strategy, Research \&amp; Development. International Journal of Tourism and Hospitality in Asia Pasific, 3(2), 97-104. https://doi.org/10.32535/ijthap.v3i2.827

Wu, Y. J., Liu, W.-J., \& Yuan, C.-H. (2020). A mobile-based barrier-free service transportation platform for people with disabilities. Computers in Human Behavior, 107, 105776. https://doi.org/10.1016/j.chb.2018.11.005

Yadav, M., Joshi, Y., \& Rahman, Z. (2015). Mobile Social Media: The New Hybrid Element of Digital Marketing Communications. Procedia - Social and Behavioral Sciences, 189, 335343. https://doi.org/10.1016/j.sbspro.2015.03.229

Zhang, H., \& Lu, X. (2020). Vehicle communication network in intelligent transportation system based on Internet of Things. Computer Communications, 160, 799-806. https://doi.org/10.1016/j.comcom.2020.03.041 